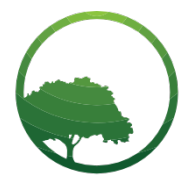

Research in Business \& Social Science

IJRBS VOL 8 NO 5 ISSN: 2147-4478

\title{
Focus strategy-firm structure fit and performance of star rated hotels in Kenya
}

Jane Nyokabi ${ }^{a}{ }^{*}$, Maina Muchara ${ }^{b}$, Juliana Namada ${ }^{c}$

\begin{tabular}{l} 
A R T I C L E I N F O \\
\hline Article history: \\
Received 07 July 19 \\
Received in revised form 22 July 19 \\
Accepted 08 August 19 \\
\hline Keywords: \\
Hotels \\
Focus Strategy \\
Firm Structure \\
Strategic Fit \\
Performance \\
JEL Classification: \\
L19
\end{tabular}

\begin{abstract}
A B S T R A C T
The purpose of this study was to examine the influence of focus strategy-firm structure fit on the performance of star-rated hotels in Kenya. The study adopted the positivism research philosophy and descriptive-correlative research design. Multi-stage sampling that included proportionate stratified sampling and simple random sampling was used. The sample consisted of 267 general managers and functional managers from Kenya's three, four and five star rated vacation and town hotels as in 2018. 253 managers responded out of which 59 respondents were found to represent hotels pursuing a focus strategy. Structural equation modeling was used for hypothesis testing. The study concluded that focus strategy-firm structure fit has a significant influence on the performance of star-rated hotels in Kenya. The study recommends that a hotel's pursuit of focus strategy be internally consistent with its organizational structure.
\end{abstract}

(C) 2019 Bussecon International Academy. Hosting by SSBFNET. All rights reserved. Peer review under responsibility of Bussecon International Academy \& SSBFNET.

\section{Introduction}

Organizations pursue focus strategy by targeting specific market segments (Pearce \& Robinson, 2015). Mintzberg, Lampel, Quinn and Ghoshal (2003) emphasize that a winning strategy is one that creates a fit that locks out imitators. The concept of fit is one of contingency theory's most significant concepts in strategic management. In the contingency approach, an association between two variables influences a third variable (Blarr, 2012). It is from the contingency theory that the strategy-structure-performance theory emanates (Baier, 2008).

Seminal contributions have played a key role in creating an understanding of strategy fit (Garlichs, 2011). Chandler (1962) examined the contingent association between corporate strategy and organizational structure. In an extension of Chandler's seminal work, it was underscored that the level of fit between strategy and structure has significant impacts on performance (Rumelt, 1974). Many different scholars have consequently supported the notion that strategy-structure mis-fit has negative implications on performance (Enz, 2010; Macharia, 2014).

Hotel rating is a system of grading hotels according to their tangible and intangible characteristics as established by government or industry (WTO \& IH\&RA, 2004). In the star rating system, 1 star to 5 stars denotes basic hotel to luxurious hotel respectively (TRA, 2018). Kenya uses the East African Community common criteria of star-rating hotels. The East African Community agreed on a uniform classification of hotels as it enables marketing of the entire region as one offering multi-destination packages (Gicobi, 2016).

\footnotetext{
* Corresponding author. ORCID ID: 0000-0003-2282-6607
}

Peer review under responsibility of Bussecon International Academy.

(C) 2019 Bussecon International. Hosting by SSBFNET- Center for Strategic Studies in Business \& Finance. All rights reserved.

https://doi.org/10.20525/ijrbs.v8i5.469 
A global hotel industry research on the efficiency of hotel chains indicated that hotel chains operating in Kenya were among those that suffered least efficiency (Assaf \& Barros, 2013). At the same time, researchers have highlighted on the inadequacy of empirical data on competitive strategies of hotels in Kenya (Fwaya, Ayieko, Odhuno, \& Okech, 2009). This study was therefore timely. The objective of this study was to examine the influence of focus strategy-firm structure fit on performance of star rated hotels in Kenya. The null hypothesis formulated to guide this study was, $\mathrm{H} 0_{1}$ :Focus strategy-firm structure fit has no significant influence on performance of star rated hotels in Kenya.

\section{Literature Review}

\section{Strategy-Structure-Performance theory}

Chandler's pronouncement is that structure follows strategy. His conclusion was that when strategy is not followed by structure, an organization experiences inefficiencies (Chandler, 1990). The assumption of strategy-structure-performance theory is that strategy precedes structure (Fadeyi, Adegbuyi, Oke, \& Ajagbe, 2015). Structural renewal of firms therefore involves changing firm structure to adapt to the firm's intended strategy (Zand, 2009). Chandler's strategy-structure-performance theory is an appropriate theory in informing the phenomenon of strategic fit (Aupperle, Acar, \& Mukherjee, 2014).

Organizations pursuing focus strategy target narrow market segments (Porter, 1998a). Market segmentation decisions are informed by characteristics such as buyer groups, geographic markets or product lines (Ireland, Hoskisson, \& Hitt, 2013). Focus strategy can take the form of cost focus or differentiation focus (Ormanidhi \& Stringa, 2008). Sustainable competitive advantage is achieved when focus strategy is matched with inimitable capabilities and resources within the chosen niche market (Pearce \& Robinson, 2015).

Organizations can target to serve geographical regions that have been isolated by competitors (Pearce \& Robinson, 2015). A hotel's niche may also be influenced by its location. Hotels generate competitive advantage by enjoying geographic features such as favorable climate, cultural sites or scenic beauty. (Forgacs, 2017).

Hotels pursue focus strategy by tailoring services and products to satisfy the needs of individual customers (Pearce \& Robinson, 2015). Product and service specialty is used widely by hotels pursuing differentiation-focus strategy. Product and service specialty has been achieved in various ways from having leisure, family or business focus to offering signature food items. Specialty menus offer environmentally friendly foods such as sustainable sea foods and organic foods to attract environmentally conscious customers (Cichy \& Hickey, 2012).

A hotel may pursue focus strategy by targeting a specific social class (Pearce \& Robinson, 2015). High income earners and low income earners would most definitely have different preferences of hotel characteristics. Focus strategy through social class segmentation determines organizational factors such as employee hiring, training and decision making authority (Forgacs, 2017).

Literature reviewed informed the operationalization of firm structure. Indicators of formalization include clarity of procedures, written job descriptions and level to which informal employee discussions are encouraged in order to solve arising matters (Stacey $\&$ Mowles, 2016). The participation of employees in decision making and the level of delegated authority are measures of centralization (Thompson, Strickland, \& Gamble, 2010). Specialization may be observed through the subdivision of tasks to employees (Nebel, 1991).

Organizational strategy and organizational structure fit creates sustainable competitive advantage. Firms with focus strategy-structure fit attain optimal performance (Ireland, Hoskisson, \& Hitt, 2013). Integration of financial as well as non-financial measures of performance is encouraged in the study of organizational performance (Hough, Thompson, Strickland, \& Gamble, 2011). Financial measures include measures of profitability while non-financial measures of hotel performance include room occupancy and market share (Harris, 2013; Hassanien, Dale, \& Clarke, 2010; Iyengar, 2008).

\section{Research and Methodology}

This study adopted positivism research philosophy. This is because the study hypothesis and the research objective were distinctly described at the onset and an effective research instrument used (Petty, Thomson, \& Stew, 2012). The research was a cross sectional study that applied a descriptive and correlative research design.

The target population was 552 general managers and senior functional managers of Kenya's 69 three star, four star and five star rated vacation and town hotels listed by the Tourism Regulatory Authority of Kenya as at the year 2018. This is illustrated on table 1. 
Table 1: Population

\begin{tabular}{lll}
\hline Hotel Star Rating & Hotels & Senior managers \\
\hline Five Star rated hotels & 12 & 96 \\
\hline Four Star rated hotels & 27 & 216 \\
\hline Three Star rated hotels & 30 & 240 \\
\hline TOTAL & $\mathbf{6 9}$ & $\mathbf{5 5 2}$ \\
\hline
\end{tabular}

Source: Authors

\section{Sampling design}

Probability sampling was used in this study as it provides a sample that well represents the population (Kothari, 2004). The sampling plan in this study was multi-stage. Proportionate stratified sampling was used to divide the population into three strata of three star, four star and five star hotels from which a total of 267 managers were sampled. Selection of respondents from each stratum was done through simple random sampling. This study used Yamane (1967) sample size formula with a precision error of 0.05 . Researchers have previously increased the primary sample size in order to cater for non-response (Wen et al., 2012). The figure of 232 computed from the Yamane sample size formula was increased by an additional 15\% to cater for non-response. This gave a final sample size of 267 senior managers of 3-to-5 star rated hotels in Kenya.

\section{Data collection}

Primary data was collected by use of a structured questionnaire that was administered through drop-and-pick method.

\section{Data analysis methods}

Classification of focus strategy was done by an analysis of the mean responses to the multi-item Likert scale questionnaire. This approach has been used in past research to operationalize competitive strategy (Zahra \& Covin, 1993). Using this criterion, of the 253 respondents, 59 respondents informed the output of this analysis being respondents from hotels pursuing focus strategy.

Exploratory Factor analysis (EFA) was carried out for reduction and grouping of measurement constructs. The exploratory factor analysis output was Kaiser-Meyer-Olkin (KMO) measure of sampling adequacy, Bartlett's test of sphericity, Total Variance Explained (TVE) and pattern matrix. Normality tests were performed using skewness and kurtosis tests. The test of reliability was assessed using construct reliability and verified using Cronbach's alpha. Confirmatory factor analysis (CFA) models aided analysis of variable attributes (Brown, 2015). Structural equation modeling (SEM) was the analysis technique that was used to measure the hypothesis of this study. Structural equation modeling is an appropriate method of modelling observed or unobserved research variables (Pituch \& Stevens, 2016).

\section{Result and Discussion}

\section{Respondent role}

The study targeted general managers and senior functional managers of star rated hotels in Kenya. Functional managers that participated in the study included heads of food and beverage, housekeeping, marketing and reservation, information technology, human resource, finance, purchasing and supply chain. In the category of other hotel managers, credit managers, engineering managers, estate managers, head auditors, heads of security, and training managers were identified as having participated in the study. $5.5 \%$ of the respondents were general managers. The results are presented on figure1.

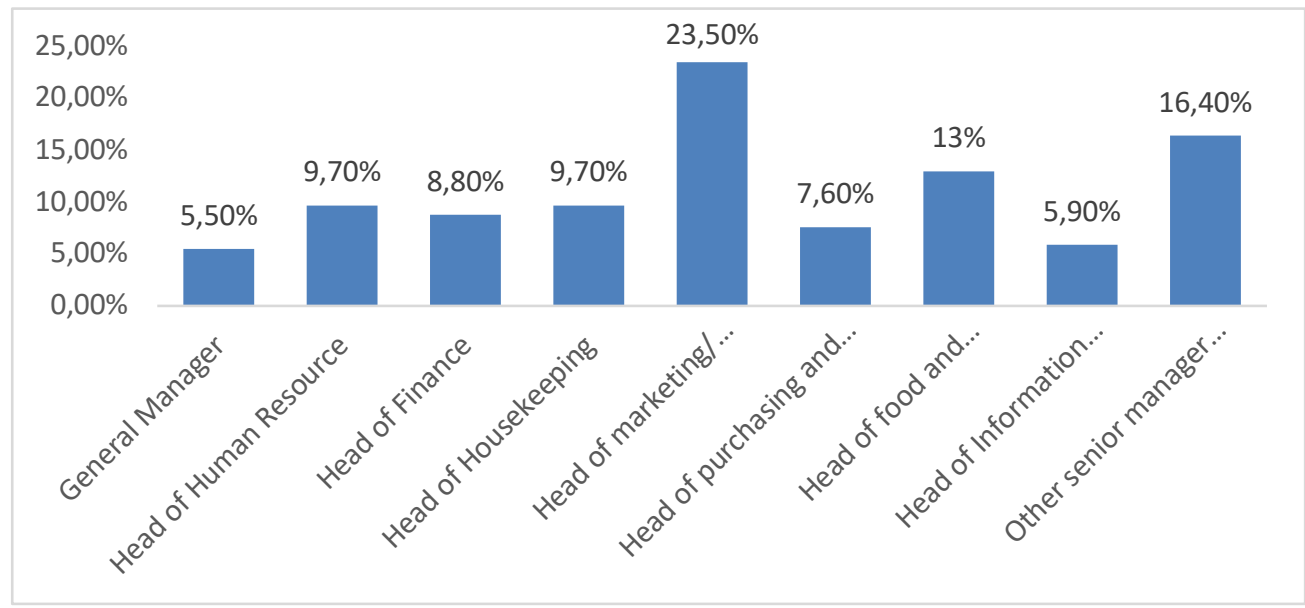

Figure 1: Respondents' Role 


\section{Respondents gender}

$41.90 \%$ of the respondents were female and $58.10 \%$ were male. This indicated that both female and male employees held a substantial percentage of managerial positions in star rated hotels in Kenya. This is presented on figure 2.

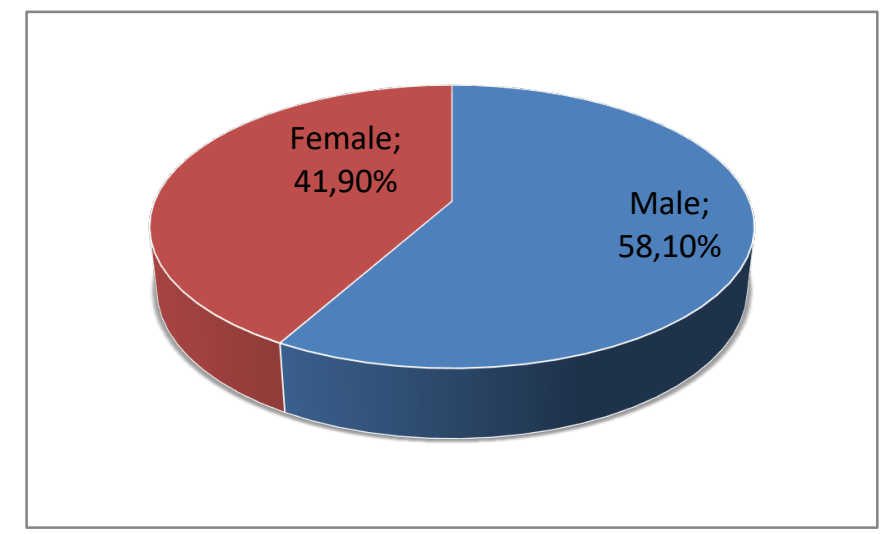

Figure 2: Respondents Gender

\section{Exploratory factor analyses}

Focus strategy was confirmed adequate for extraction with $\mathrm{KMO}=.682$ and Bartlett's test of Sphericity being significant at $\mathrm{X}^{2}(15$, $N=59)=18.712, p<.05$. Further, 3 components with eigen value $>1$ explaining $64.251 \%$ variance were extracted. On the communalities and pattern matrix, all factor loadings were suitable and $>.5$, ranging between. 713 and .803 . The 3 components of focus strategy were product and service specialty, income level and geographical region.

\section{Normality tests}

The skewness test values of normally distributed data range between -2 and +2 . The kurtosis tests values of normally distributed data range between -7 and +7 (Kline, 2015). In this study, the skewness result ranged from -.363 to 1.033 whereas the kurtosis result ranged from -1.043 to .654 . This confirmed that focus strategy data was normally distributed.

\section{Reliability tests}

Cronbach alpha values and composite reliability values $>=0.7$ show reliability of a data collection instrument (Tavakol \& Dennick, 2011). The Cronbach's alpha value was .756 and the composite reliability for focus strategy was .916. This confirms the reliability of the focus strategy items.

\section{SEM model fit indices}

In determining the influence of focus strategy-firm structure fit on performance of star rated hotels in Kenya, the SEM model fit indices were excellent. $\mathrm{CMIN} / \mathrm{DF}=1.957$ (excellent when between 1 and 3), $\mathrm{CFI}=.913$ (excellent at $>0.90$ ), RMSEA $=.062$ (excellent at $<0.08$ ) and PCLOSE $=.051$ (acceptable at $>.05$ ). 


\section{Hypothesis testing using structural equation modeling}

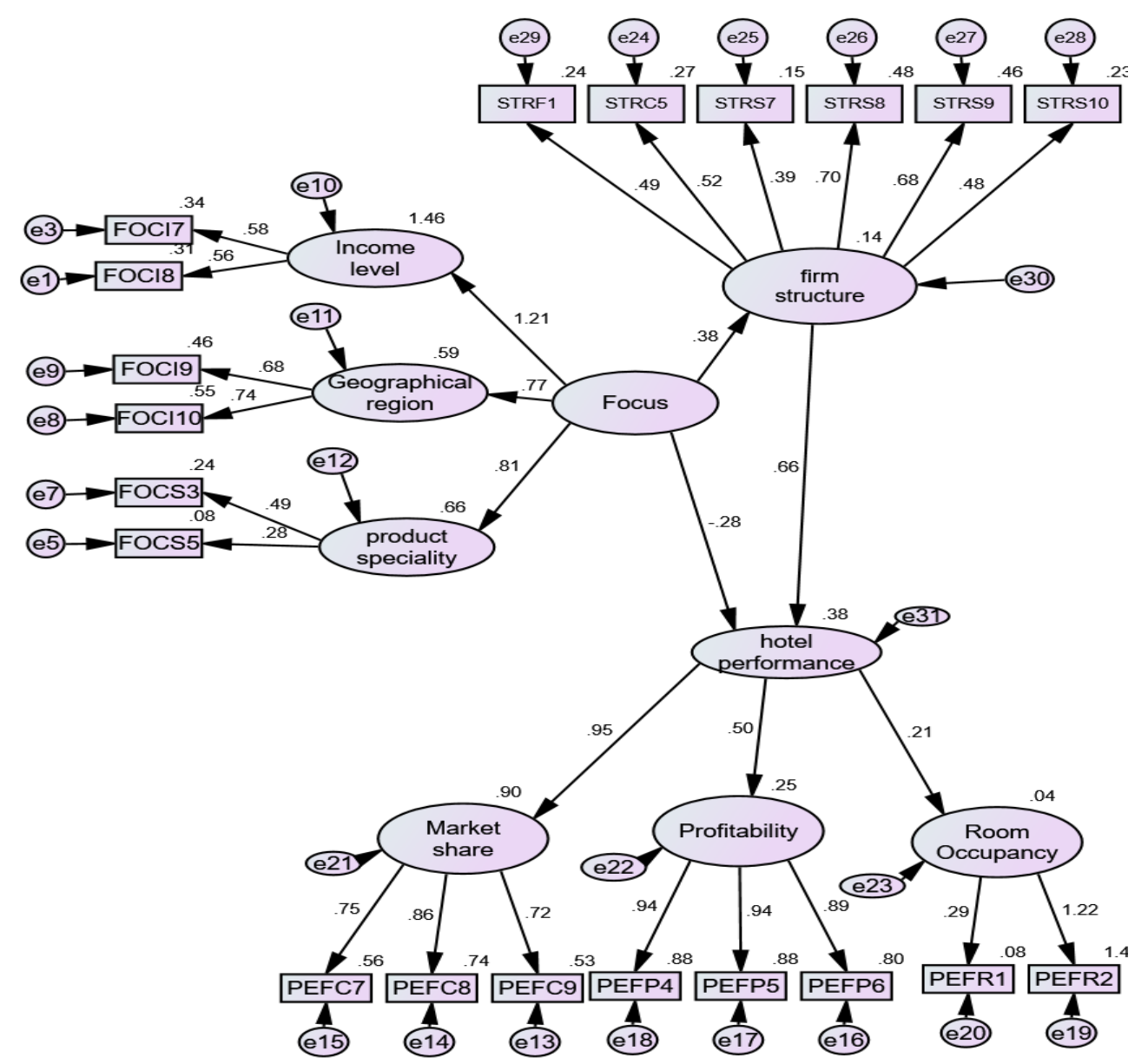

Figure 3: Structural equation model of influence of focus strategy-firm structure fit on hotel performance

$\mathrm{R}^{2}$ obtained from the SEM model in figure 3 explains the degree of variance by focus strategy-firm structure fit on hotel performance. Focus strategy explained $14 \%\left(\mathrm{R}^{2}=.14\right)$ of the variance in firm structure. Further, the model shows that focus strategy-firm structure fit explained $38 \%\left(\mathrm{R}^{2}=.38\right)$ of the variance in hotel performance. The remaining $62 \%$ was explained by other factors not included in this study.

Table 2: Path Coefficients of Influence of Focus Strategy-Firm Structure Fit on Hotel Performance

\begin{tabular}{|c|c|c|c|c|c|c|c|}
\hline Path & & & $\begin{array}{l}\text { Unstandardized } \\
\text { estimates }\end{array}$ & $\begin{array}{l}\text { Standardized } \\
\text { estimates } \\
\text { Beta }\end{array}$ & $\begin{array}{l}\text { Standard } \\
\text { Error }\end{array}$ & $\begin{array}{l}\text { C.R. } \\
\text { T- } \\
\text { value }\end{array}$ & $p$ \\
\hline Firm structure & $<---$ & Focus strategy & .230 & .378 & .070 & 3.273 & .001 \\
\hline hotel performance & $<---$ & Firm structure & .566 & .663 & .147 & 3.849 & $* * *$ \\
\hline Hotel performance & $<---$ & Focus strategy & -.144 & -.278 & .050 & -2.857 & .004 \\
\hline
\end{tabular}

Source: Authors

As presented on table 2, the path coefficient for the relationship between focus strategy to hotel performance was negative and significant $(\beta$ eta $=-0.278, \mathrm{~T}$-value $=-2.857, \mathrm{p}<0.05)$. This shows that the direct influence of focus strategy on hotel performance was negative in this model. The path coefficient for the relationship between focus strategy to firm structure of hotels was positive and significant $(\beta$ eta $=0.378, T$-value $=3.273, p<0.05$ ). The positive relationship indicates that a unit increase in focus strategy increases firm structure by .378 . Similarly, the path coefficient of focus strategy-firm structure fit to hotel performance was positive and significant $(\beta e t a=0.663, \mathrm{~T}$-value $=3.849, \mathrm{p}<0.05$ ). The positive relationship indicates that a unit increase in focus strategy-firm structure fit increases hotel performance by .663. 
This rejects the null hypothesis of study, $\mathrm{H}_{1}$ : Focus strategy-firm structure fit has no significant influence on performance of star rated hotels in Kenya and accepts the alternate hypothesis; $\mathrm{H}_{1}$ : Focus strategy-firm structure fit has significant influence on performance of star rated hotels in Kenya.

\section{Conclusions}

This study examined the influence of focus strategy-firm structure fit on performance of star rated hotels in Kenya. The positivism research philosophy and descriptive-correlative research design were adopted in the study. Multi-stage sampling that included proportionate stratified sampling and simple random sampling was used. The sample consisted of 267 general managers and functional managers from Kenya's three, four and five star rated vacation and town hotels as at 2018. 253 managers responded out of which 59 respondents were found to represent hotels pursuing focus strategy. Structural equation modeling was used for hypothesis testing. The study concluded that focus strategy-firm structure fit has significant influence on performance of star rated hotels in Kenya. The study recommends that a hotel's pursuit of focus strategy be internally consistent with its organizational structure. The study also recommends to hotel managers pursuing niche markets based on geographical region, service specialty or income level of consumers to ensure a fit between their strategy and firm structure. Finally, this study recommends further study of other internal organizational factors whose fit with strategy positively impacts hotel performance.

\section{References}

Assaf, G., \& Barros, C. (2013). A Global Benchmarking of the Hotel Industry. Tourism Economics, 19(4), 811-821. doi:10.5367/te.2013.0230

Aupperle, K., Acar, W., \& Mukherjee, D. (2014). Revisiting the fit-performance thesis half a century later: a historical financial analysis of Chandler's own matched and mismatched firms. (T. \&. Francis, Ed.) Business History, 56(3), 341-371.

Baier, C. (2008). The Alignment Performance Link in Purchasing and Supply Management: Performance Implications of Fit between Business Strategy, Purchasing Strategy, and Purchasing Practices. Gabler-Verlag.

Blarr, H. (2012). Organizational Ambidextrity: Implications for the Strategy-Performance Linkage. Springer Gabler.

Brown, T. A. (2015). Methodology in the Social Sciences: Confirmatory Factor Analysis for Applied Research. (D. Kenny, Ed.) Guilford Publications.

Chandler, A. (1962). Strategy and Structure: Chapters in the History of American Enterprise. Cambridge: M.I.T Press.

Chandler, A. (1990). Strategy and Structure: Chapters in the History of the American Industrial Enterprise By Alfred Chandler. Massachusetts: Massachussetts Institute of Technology.

Cichy, R., \& Hickey, P. (2012). Managing Service in Food and Beverage Operations (4th ed.). Michigan: American Hotel \& Lodging Educational Institute.

Enz, C. A. (2010). Hospitality Strategic Management: Concepts and Cases (2nd ed.). Hoboken, New Jersey: John Wiley \& Sons, Inc.

Fadeyi, O., Adegbuyi, A., Oke, A., \& Ajagbe, M. (2015). Review of Organizational Strategy and Structure (1962-2015). International Conference on African Development Issues (CU-ICADI) 2015: Social and Economic Models for Development Track, (pp. 341-348).

Forgacs, G. (2017). Revenue Management: Maximizing Revenue in Hospitality Operations (2nd ed.). Michigan: American Hotel and Lodging Educational Institute.

Fwaya, E., Ayieko, M., Odhuno, E., \& Okech, R. (2009). The Role of Human Resource Systems and Competitive Strategies in Hospitality Organizational Performance in Kenya. International Journal of Hospitality \& Tourism Administration, 10(2), 174-194.

Garlichs, M. (2011). The Concept of Fit. Hamburg: Diplomica Verlag.

Gicobi, m. (2016, August 27). Region Classifies Hotels to Enable Joint East African Marketing. Nairobi. Retrieved June 23, 2017, from http://www.theeastafrican.co.ke/business/Region-classifies-hotels-to-enable-joint-East-African-marketing-/25603360130-tcfqplz/index.html

Harris, P. (2013). Profit Planning for Hospitality and Tourism (Extended 3rd ed.). Oxford: Goodfellow Publishers Limited.

Hassanien, A., Dale, C., \& Clarke, A. (2010). Hospitality Business Development. Elsevier Limited.

Hough, J., Thompson, A., Strickland, A. J., \& Gamble, J. (2011). Crafting and Executing Strategy: Creating Sustainable High Performance in South African Businesses (2nd ed.). Berkshire: McGraw-Hill Education.

Ireland, D. R., Hoskisson, R. E., \& Hitt, M. A. (2013). The Management of Strategy: Concepts and Cases (10th ed.). Canada: SouthWestern, Cengage Learning.

Iyengar, A. (2008). Hotel Finance. New Delhi, India: Oxford University Press.

Kline, R. B. (2015). Principles and Practice of Structural Equation Modelling (4th ed.). Guilford Publications.

Kothari, C. R. (2004). Research methodology: Methods and techniques. New Age International.

Macharia, W. N. (2014, November). Competitive Strategy, Organizational Competencies Co-alignment, Macro Environment and Perfomance of Private Middle Level Colleges in Nairobi County, Kenya. Unpublished PhD Thesis, School of Business, University of Nairobi. 
Mintzberg, H., Lampel, J., Quinn, B., \& Ghoshal, S. (2003). The Strategy Process: Concepts, Contexts and Cases. Upper Saddle River, New Jersey: Pearson Education.

Nebel, E. (1991). Managing Hotels Effectively: Lessons from Outstanding General Managers. Canada: John Wiley \& Sons.

Ormanidhi, O., \& Stringa, O. (2008, July). Porter's Model of Generic Competitive Strategies. pp. 55-64.

Pearce, J., \& Robinson, R. (2015). Strategic Management: Planning for Domestic \& Global Competition (14th ed.). New York: McGraw-Hill Education.

Petty, N. J., Thomson, O. P., \& Stew, G. (2012). Ready for a paradigm shift? Part 1: introducing the philosophy of qualitative research. Manual therapy, 17(4), 267-274.

Pituch, K., \& Stevens, J. (2016). Applied Multivariate Statistics for the Social Sciences: Analyses with SAS and IBM's SPSS (6th ed.). New York: Taylor \& Francis.

Porter, M. E. (1998a). Competitive Strategy: Techniques for Analyzing Industries and Competitors: With A New Introduction. New York: The Free Press.

Rumelt, R. (1974). Strategy, Structure, and Economic Performance. Harvard University Press: Cambridge.

Stacey, R., \& Mowles, C. (2016). Strategic Management and Organizational Dynamics: The Challenge of Complexity to Ways of Thinking About Organizations (7th ed.). Harlow, United Kingdom: Pearson Education Limited.

Tavakol, M., \& Dennick, R. (2011). Making sense of Cronbach's alpha. International Journal of Medical Education, 2, 53-55.

Thompson, A. A., Strickland, A. J., \& Gamble, J. E. (2010). Crafting and Executing Strategy: Text and Readings (17th ed.). New York: McGraw-Hill Irwin.

TRA. (2018). Classified Tourism Enterprises. Retrieved November 6, 2018, from Tourism Regulatory Authority: https://www.tourismauthority.go.ke/index.php/resource-centre/downloads/category/12-classified-tourism-enterprises

Wen, J., Shi, Y.-k., Li, Y.-p., \& Wang, F. (2012). Quality of Life, Physical Diseases, and Psychological Impairment among Survivors 3 Years after Wenchuan Earthquake: A Population Based Survey. PLOS ONE, 7(8), 1-7.

WTO \& IH\&RA. (2004). The Joint WTO \& IH\&RA Study on Hotel Classification. Retrieved July 4, 2017, from https://www.yumpu.com/en/document/view/43957204/the-joint-wto-amp-ihampra-study-on-hotel-classification-hoteldesigns

Yamane, T. (1967). Elementary sampling theory. Prentice-Hall.

Zahra, S. A., \& Covin, J. G. (1993, September). Business Strategy, Technology Policy and Firm Performance. Strategic Management Journal, 14(6), 451-478.

Zand, D. E. (2009). Strategic renewal: how an organization realigned structure with strategy. Strategy \& Leadership, 37(3), 23-28. 